\title{
Effect of Geographical Location, Year, and Cultivar on Survival of Malus sp. Dormant Buds Stored in Vapors of Liquid Nitrogen
}

\author{
Maria M. Jenderek ${ }^{2}$ \\ National Center for Genetic Resources Preservation, USDA-ARS, 111 \\ Mason Street, Fort Collins, CO 80521 \\ Phil Forsline \\ Plant Genetic Resources Unit, USDA-ARS, Geneva, NY 14456
}

\section{Joseph Postman \\ National Clonal Germplasm Repository, USDA-ARS, Corvallis, OR 97333}

\author{
Ed Stover ${ }^{1}$ \\ National Germplasm Repository, USDA-ARS, Davis, CA 95616
}

\section{David Ellis \\ National Center for Genetic Resources Preservation, USDA-ARS, Fort Collins, CO 80521}

Additional index words. apple, cryopreservation, desiccation, genetic resources, genebanking, germplasm, dormant bud viability

\begin{abstract}
Clonal woody crop germplasm collections often originate and are grown in distinct geographical locations. Because the degree of cold-hardiness is known to be a factor in the successful use of dormant bud cryopreservation for Malus, it was suggested that material from relatively warmer climates would not respond to cryopreservation as well as material from colder environments. To test this hypothesis, the effect of growing provenance on cryosurvival of dormant buds from three Malus (apple) cultivars grown in three locations (Geneva, NY; Davis, CA; and Corvallis, OR) was tested in 3 consecutive years. Dormant winter buds were harvested at the three locations, cryopreserved, and bud viability was tested by grafting. The collective 3-year mean viability for cryopreserved dormant apple buds for the three locations ranged from $63 \%$ to $81 \%$ of the buds surviving with the highest survival from the Corvallis site; however, the Geneva twigs were exposed to the lowest preharvest temperature. These results suggest that the temperature at the growing location may not hinder application of the dormant bud cryopreservation method with Malus to the extent previously speculated.
\end{abstract}

Although many plant germplasm collections can be easily and securely stored long

\footnotetext{
Received for publication 7 Oct. 2010. Accepted for publication 1 July 2011.

We express our sincere gratitude to Dr. Mark West for his assistance in the statistical evaluation of the data, to M.S. Barbara Ambruzs for her technical assistance in processing the material, to Mr. William Srmack at the PGRU, Geneva, NY, for performing the graft recovery in each of the 3 years of the study, and to Drs. Barbara Reed and P. Purdy for constructive reviews of the manuscript.

USDA is an equal opportunity provider and employer.

Mention of trade names or commercial products in this publication is sole for the purpose of providing specific information and does not imply recommendation or endorsement by the U.S. Department of Agriculture.

${ }^{1}$ Current address: U.S. Horticultural Research Laboratory, USDA-ARS, Fort Pierce, FL 34945.

${ }^{2}$ To whom reprint requests should be addressed; e-mail maria.jenderek@ars.usda.gov.
}

term as seed, a large group of plant genetic resources are clonally propagated crops and need to be stored in a vegetative state, often in field plantings, liquid nitrogen, or both. Cryopreservation safeguards the genetic resources from abiotic and biotic stress. In the USDAARS germplasm collection, over 100 Malus (apple) accessions were lost to disease in the field gene bank and exist today only because they were cryopreserved earlier as a secure backup and recovered from the stored buds by grafting (Forsline, personal communication).

The cryopreservation of Malus using dormant buds (DBs) represents one of the easiest methods for cryopreserving clonally propagated plant germplasm collections. DBs are harvested from field-grown trees during winter dormancy. Single-node segments are slowly desiccated and slow cooled to $-30{ }^{\circ} \mathrm{C}$ and then stored in liquid nitrogen vapor (LNV). To recover the tissue from the cryostorage, the DB segments are slowly rehydrated and chip-grafted onto rootstocks in a greenhouse or in the field (Forsline et al., 1998; Seufferheld et al., 1999).
Survival of dormant cryopreserved buds was reported for apple (Malus sp.; Forsline et al., 1998; Seufferheld et al., 1999), ash (Fraxinus; Volk et al., 2009); elm (Ulmus sp.; Harvengt et al., 2004), mulberry (Morus bombycis Koidz:; Niino et al., 1995), pear (Pyrus sp.; Suzuki et al., 1997), persimmon (Diospyros kaki Thumb.; Matsumoto et al., 2001), silver birch (Betula pendula Roth.; Ryynänen, 1996), Scots pine (Pinus sylvestris L.; Kuoksa and Hohtola, 1991), willow (Salix sp.; Towill and Widrlechner, 2004), and several other species (Towill and Ellis, 2008). At the National Center for Genetic Resources Preservation (NCGRP), dormant winter buds are routinely used in cryopreservation of apple (Malus sp.) (Forsline et al., 1998; Towill and Bonnart, 2005; Towill et al., 2004; Volk et al., 2008) and sour cherry (Prunus cerasus L.; Towill and Forsline, 1999) germplasm collections. DBs have not successfully been used to cryopreserve germplasm collections of other woody crops despite extensive research. There are several potential reasons that this cryopreservation method is not readily or widely transferable to other germplasm collections, including a lack of adequate dormancy or cold-hardiness for bud survival, difficulties of chip grafting for the particular crop, the lack of proper desiccation, slow cooling or recovery methodology, a genotypic-specific response, or lack of other physiological attributes resulting from the geographic location where the donor material was grown (Forsline et al., 1998; Towill and Bonnart, 2005; Tyler and Stushnoff, 1988b).

The geographic location in which the material was grown can account for differing levels of adaptive environmental freezing tolerance that may be related to cryotolerance (Sakai, 1965; Towill and Widrlechner, 2004). In Australian wild citrus species (Citrus, austrlasica, C. indora, and C. garrawayi), cryopreservation tolerance in seeds was related to geographical origin of the seeds (Hamilton et al., 2009). Phenological studies in Scots pine (Pinus sylvestris L.) and lodgepole pine ( $P$. contorta var, latifolia Engelm.) showed a positive relationship of frost tolerance and cold acclimation to their geographical origin (Nilsson, 2001), whereas the latitude of origin in Arabidopsis thaliana was reported to have a significant positive relationship to freezing tolerance (Zhen, 2009; Zhen and Ungerer, 2008). Winter buds of Pseudotsuga menziessi grown in Idaho and Colorado survived freezing to $-50{ }^{\circ} \mathrm{C}$ where buds from the Pacific coast in western North America withstand freezing only to $-20{ }^{\circ} \mathrm{C}$ (Sakai, 1983; Sakai and Weiser, 1973). Other factors including desiccation tolerance and pre-liquid nitrogen freezing temperature also play a role in the cryopreservation success of DB. Tyler and Stushnoff (1988b) reported a higher survival in liquid nitrogen of desiccated dormant buds than of non-desiccated buds. In their study with three apple cultivars, variation in moisture accounted for $64 \%$ to $77 \%$ of the variation in survival after cryopreservation. Cold-hardening was the highest in December 
and January and dehydration to $25 \%$ to $30 \%$ moisture content resulted in the highest post cryosurvival for the apple cultivars tested (Tyler and Stushnoff, 1988a, 1988b). Prefreezing temperature also had an effect on dormant apple bud survival in liquid nitrogen with exposure to $-30{ }^{\circ} \mathrm{C}$ for $24 \mathrm{~h}$ reported to be the most optimal for cryopreservation of dormant apple buds (Tyler et al., 1988).

Germplasm collections include genotypes with varying degrees of cold-hardiness and these differences need to be taken into account when applying cryopreservation protocols. The Malus dormant bud cryopreservation system appears to be such a system, yet extending this system to other crops, particularly Prunus species (apricot, almond, peaches, and sweet cherries) and Pyrus (pears), is difficult. A proposed rationale for the lack of dormant bud survival in Prunus and Pyrus after cryopreservation is an absence of adequate coldhardening in field genebanks, i.e., Davis, CA and Corvallis, OR. In contrast, the Malus field genebank is located in a much colder region of the United States, Geneva, NY. Could Malus DB from trees grown in California or Oregon be successfully cryopreserved similar to DB harvested in New York?

This study investigated post-cryoviability of DB for three commercial cultivars of Malus domestica grown in three distinct geographic locations, Geneva, NY, Davis, CA, and Corvallis, OR.

\section{Material and Methods}

The commercial $M$. domestica cultivars Braeburn, Jonagold, and Liberty, all classified as intermediate in cold-hardiness (Towill et al., 2004), were chosen because orchards containing these cultivars already existed in close proximity to the field genebanks in the three locations of the National Plant Germplasm System (NPGS) clonal fruit-tree genebanks (Geneva, NY, Davis, CA, and Corvallis, OR). During January in 3 consecutive years (2007, 2008, and 2009), 1-year-old twigs $\approx 5$ to 7 $\mathrm{mm}$ in diameter containing DBs from the three cultivars were harvested at the three locations (Table 1). The number of days between harvest and the beginning of the DB processing varied over the 3 years, however, was similar for the three locations in a given year (Table 2). At the time the material was harvested, all twigs appeared fully dormant. The mean minimum temperatures for November, December, and January before harvest at the three locations are listed in Table 3 . The cuttings were sealed in plastic bags and shipped by overnight carrier to the NCGRP in Fort Collins, CO, where they were placed in a $-5{ }^{\circ} \mathrm{C}$ chamber and sealed

Table 1. Geographical coordinates and altitudes of dormant bud harvest locations.

\begin{tabular}{lcrc}
\hline Location & Latitude & Longitude & $\begin{array}{c}\text { Elevation } \\
(\mathrm{m})\end{array}$ \\
\hline Geneva, NY & $42^{\circ} 52^{\prime} \mathrm{N}$ & $76^{\circ} 58^{\prime} \mathrm{W}$ & 373.6 \\
Davis, CA & $38^{\circ} 32^{\prime} \mathrm{N}$ & $121^{\circ} 58^{\prime} \mathrm{W}$ & 41.1 \\
Corvallis, OR & $44^{\circ} 34^{\prime} \mathrm{N}$ & $123^{\circ} 16^{\prime} \mathrm{W}$ & 75.0 \\
\hline
\end{tabular}

in the plastic bags until processed for cryopreservation (Table 2).

The cryoprocessing method described for Malus DB by Forsline et al. (1998) was used. Twigs were cut into one-node segments (35 $\mathrm{mm}$ long) with a $30-\mathrm{cm}$ band saw and desiccated in mesh bags 8 to $20 \mathrm{~d}$ (Table 4 ) at $-5^{\circ} \mathrm{C}$ over silica gel desiccant ( 28 to 200 mesh; recharged at $90{ }^{\circ} \mathrm{C}$ or replaced each third day) under fan-circulated air. Single-node twig segments were desiccated from initial moisture content (MC) of $43.9 \%$ to $53.1 \%$ (Table 5) to $25 \%$ to $30 \% \mathrm{MC}$. MC was established by a comparison of experimental samples to oven-dried samples $\left(90^{\circ} \mathrm{C}\right)$. The experimental samples were weighed each second day until desiccated to $25 \%$ to $30 \% \mathrm{MC}$. The single-node twig segments were then placed in heat-sealed polyolefin tubes and slowly cooled to $-30{ }^{\circ} \mathrm{C}$ at $1{ }^{\circ} \mathrm{C} / \mathrm{h}$, held at $-30{ }^{\circ} \mathrm{C}$ for 24 h (in 2007, Sun Electronics System, Inc. cooler; in 2008 to 2009 , SIGMA C4 Controller) and after placed directly into LNV ( -170 to $-180{ }^{\circ} \mathrm{C}$ ) in a $915 \mathrm{~L}$ cryotank (MVE 1842P150; Chart Industries, USA) for a minimum of $4 \mathrm{~d}$. Control nodal segments were treated as described previously but were not exposed to LNV (i.e., desiccated to $25 \%$ to $30 \% \mathrm{MC}$, chilled to $-30{ }^{\circ} \mathrm{C}$ ); they were kept at $-5{ }^{\circ} \mathrm{C}$ until shipment for grafting together with the LNV-treated DB. After the LNV exposure, the nodal segments were warmed in a refrigerator $\left(+4{ }^{\circ} \mathrm{C}\right)$ overnight and together with the control nodal segments were shipped to Geneva, NY, by overnight carrier.

Table 2. Apple twig harvest dates at Geneva, NY, Davis, CA, and Corvallis, OR, during 2007 to 2009.

\begin{tabular}{lcccc}
\hline Location & Yr & Harvest date & Processing date & $\begin{array}{c}\text { Number of days between } \\
\text { harvest }^{z} \text { and processing }\end{array}$ \\
\hline Geneva, NY & 2007 & 30 Jan. & 5 Feb. & 6 \\
& 2008 & 14 Jan. & 29 Jan. & 15 \\
& 2009 & 12 Jan. & 3 Feb. & 22 \\
Davis, CA & & & $5 \mathrm{Feb}$. & 5 \\
& 2007 & 31 Jan. & $29 \mathrm{Jan}$. & 13 \\
& 2008 & 16 Jan. & 3 Feb. & 14 \\
Corvallis, OR & 2009 & 19 Jan. & & 6 \\
& 2007 & 30 Jan. & 5 Feb. & 15 \\
& 2008 & 14 Jan. & 29 Jan. & 22 \\
\hline
\end{tabular}

${ }^{2}$ Beginning of twig cutting.

Table 3. Average minimum temperature during November, December, and January for Geneva, NY, Davis, CA, and Corvallis, OR.

\begin{tabular}{|c|c|c|c|c|c|c|}
\hline \multirow[b]{2}{*}{ Location } & \multirow[b]{2}{*}{ Yr of twig harvest } & \multirow{2}{*}{$\begin{array}{c}\text { Temperature } \\
\text { in yr }\end{array}$} & \multicolumn{3}{|c|}{ Monthly mean temp. $\left({ }^{\circ} \mathrm{C}\right)$} & \multirow{2}{*}{$\begin{array}{l}\text { Avg/ } \\
\text { season }\end{array}$} \\
\hline & & & January $^{z}$ & November & $\overline{\text { December }}$ & \\
\hline \multirow[t]{7}{*}{ Geneva, NY } & 2007 & 2006 & & 2.5 & -1.1 & \\
\hline & & 2007 & -6.0 & & & -1.5 \\
\hline & 2008 & 2007 & & 0.9 & -5.3 & \\
\hline & & 2008 & -2.7 & & & -2.4 \\
\hline & 2009 & 2008 & & -0.3 & -5.8 & \\
\hline & & 2009 & -11.5 & & & -5.8 \\
\hline & Average/location & & -6.7 & 1.0 & -4.0 & -3.2 \\
\hline \multirow[t]{7}{*}{ Davis, CA } & 2007 & 2006 & & 6.2 & 2.8 & \\
\hline & & 2007 & -0.4 & & & 2.9 \\
\hline & 2008 & 2007 & & 4.7 & 2.1 & \\
\hline & & 2008 & 3.1 & & & 3.3 \\
\hline & 2009 & 2008 & & 6.6 & 0.9 & \\
\hline & & 2009 & 0.1 & & & 2.5 \\
\hline & Average/location & & 0.9 & 5.8 & 1.9 & 2.9 \\
\hline \multirow[t]{7}{*}{ Corvallis, OR } & 2007 & 2006 & & 5.2 & 1.4 & \\
\hline & & 2007 & -0.06 & & & 2.2 \\
\hline & 2008 & 2007 & & 2.2 & 2.0 & \\
\hline & & 2008 & 2.4 & & & 2.2 \\
\hline & 2009 & 2008 & & & & \\
\hline & & 2009 & 3.6 & & & 3.2 \\
\hline & Average/location & & 1.98 & 4.5 & 3.3 & 2.5 \\
\hline
\end{tabular}

zJanuary mean temperature up to harvest date.

Table 4. Number of desiccation days needed to obtain $25 \%$ to $30 \%$ moisture content in dormant apple buds harvested at Geneva, NY, Davis, CA, and Corvallis, OR, during 2007 to 2009.

\begin{tabular}{|c|c|c|c|c|c|c|c|c|c|}
\hline \multirow[b]{2}{*}{ Location } & \multicolumn{3}{|c|}{ Braeburn } & \multicolumn{3}{|c|}{ Jonagold } & \multicolumn{3}{|c|}{ Liberty } \\
\hline & 2007 & 2008 & 2009 & 2007 & 2008 & 2009 & 2007 & 2008 & 2009 \\
\hline Geneva, NY & 10 & 18 & 16 & 13 & 13 & 16 & 10 & 15 & 14 \\
\hline Davis, CA & 10 & 17 & 20 & 10 & 17 & 14 & 10 & 16 & 10 \\
\hline Corvallis, OR & 8 & 18 & 14 & 8 & 16 & 14 & 11 & 16 & 14 \\
\hline
\end{tabular}


At Geneva, the nodal segments from both treatments (control and LNV) were rehydrated for $14 \mathrm{~d}$ in moist peatmoss at $2{ }^{\circ} \mathrm{C}$ and then the buds were chip-grafted onto domestic seedling rootstock in a greenhouse as described by Forsline et al. (1998). Grafted buds were scored as alive (pushing out, growing, green, and forming a shoot) or dead (not pushing out, appearing brown) 8 to 10 weeks after grafting in March of each year.

The experiment was set up in a completely randomized design. The data were evaluated by analysis of variance (Tukey-Kramer honestly significant difference) and the effect of interactions among location, year, and cultivars were tested by a fit model analysis (JMP 7.0; SAS Institute, Inc., Cary, NC). Correlation between the control DB and LNV-exposed viabilities was tested by a multivariate method (Pearson's coefficient). F statistics were considered significant when the reported $P$ values were $<0.05$.

\section{Results and Discussion}

The mean viability (\%) of cryopreserved dormant buds was significantly lower than the mean viability of the control buds $(73.6 \%$ and $82.6 \%$, respectively, mean for all years, in all locations and for all cultivars tested); however, the data showed a high correlation between viabilities (\%) within a year, location, and cultivar of the control (desiccated, slow cooled to $-30{ }^{\circ} \mathrm{C}$, hold for $24 \mathrm{~h}$ ) and the LNVexposed DB $(0.70 ; P<0.001)$. In 2007 , the viability of the cryopreserved material varied significantly and ranged from 15.5 ('Braeburn', NY) to $96.2 \%$ ('Liberty', OR; Table 6). The 2008 viability of cryopreserved DB was not significantly different between cultivars and locations and ranged from $66.7 \%$ to $86.7 \%$. In 2009, only 'Braeburn' from California had a significantly lower viability $(60.0 \%)$ than cryopreserved DB of the other cultivars from all three locations including 'Braeburn' from New York and Oregon. The mean post-cryopreservation viability in all 3 years and the three locations was significantly lower for 'Braeburn' than for 'Liberty' (Table 7).

In 2007, the mean of DB post-cryopreservation viability (\%) for the three cultivars was significantly lower for Geneva than for Corvallis. In 2008 and 2009, the mean viabilities were not significantly different; however, the 3-year mean of the three cultivars for each location was significantly lower for the Geneva than for Corvallis $(63.4 \%$ and $81.0 \%$, respectively; Table 8). Results based on grafting of control (desiccated and cooled to $-30{ }^{\circ} \mathrm{C}$ ) and cryopreserved DB indicate that viabilities were lower in 2007 than in 2008 or 2009 (Table 9). These lower viabilities in 2007 may be the result of two equipment failures that caused a delay and warming up of the samples during the slow cooling process. On two different occasions, a lapse of nitrogen flow during slow cooling caused a brief temperature increase from -24 to $43{ }^{\circ} \mathrm{C}$ and from -5 to $12^{\circ} \mathrm{C}$; after, the slow cooling was completed without incident. However, DBs from all locations and cultivars were in the same slow

Table 5. Initial moisture content (\%) in three cultivars of dormant apple twigs harvested at Geneva, NY, Davis, CA, and Corvallis, OR.

\begin{tabular}{|c|c|c|c|c|c|c|c|c|c|}
\hline \multirow[b]{2}{*}{ Location } & \multicolumn{3}{|c|}{ Braeburn } & \multicolumn{3}{|c|}{ Jonagold } & \multicolumn{3}{|c|}{ Liberty } \\
\hline & 2007 & 2008 & 2009 & 2007 & 2008 & 2009 & 2007 & 2008 & 2009 \\
\hline Geneva, NY & 53.1 & 49.8 & 49.3 & 46.7 & 49.7 & 50.4 & 43.9 & 47.7 & $\overline{46.4}$ \\
\hline Davis, CA & 50.8 & 49.3 & 48.0 & 50.0 & 48.8 & 48.4 & 47.9 & 47.4 & 47.7 \\
\hline Corvallis, OR & 47.1 & 51.2 & 52.2 & 46.0 & 48.9 & 51.6 & 46.7 & 49.0 & 51.6 \\
\hline
\end{tabular}

Table 6. Mean post-cryopreservation viability (\%) of three cultivars of apple dormant buds harvested at three locations during 2007 to 2009 that were cooled to $-30{ }^{\circ} \mathrm{C}$ or cooled to $-30{ }^{\circ} \mathrm{C}$ and stored in LNV, rehydrated, and grafted onto rootstocks.

\begin{tabular}{|c|c|c|c|c|c|c|c|}
\hline \multirow[b]{2}{*}{ Cultivar } & \multirow[b]{2}{*}{ Location } & \multicolumn{2}{|c|}{2007} & \multicolumn{2}{|c|}{2008} & \multicolumn{2}{|c|}{2009} \\
\hline & & $-30^{\circ} \mathrm{C}$ & LNV & $-30^{\circ} \mathrm{C}$ & LNV & $-30^{\circ} \mathrm{C}$ & LNV \\
\hline \multirow[t]{3}{*}{ Braeburn } & Geneva, NY & $20.2 \mathrm{a}$ & $15.5 \mathrm{c}^{\mathrm{z}}$ & $76.7 \mathrm{~b}$ & $70.0 \mathrm{a}$ & $60.0 \mathrm{~b}$ & $56.7 \mathrm{ab}$ \\
\hline & Davis, CA & $49.1 \mathrm{a}$ & $57.7 \mathrm{abc}$ & $83.9 \mathrm{ab}$ & $68.3 \mathrm{a}$ & $78.3 \mathrm{ab}$ & $60.0 \mathrm{~b}$ \\
\hline & Corvallis, OR & $95.5 \mathrm{a}$ & $77.9 \mathrm{ab}$ & $96.7 \mathrm{ab}$ & $73.3 \mathrm{a}$ & $76.7 \mathrm{ab}$ & $70.0 \mathrm{ab}$ \\
\hline \multirow[t]{3}{*}{ Jonagold } & Geneva, NY & $56.1 \mathrm{a}$ & $49.4 \mathrm{abc}$ & $76.7 \mathrm{~b}$ & $76.7 \mathrm{a}$ & $73.3 \mathrm{ab}$ & $80.0 \mathrm{ab}$ \\
\hline & Davis, CA & $44.1 \mathrm{a}$ & $44.3 \mathrm{bc}$ & $96.7 \mathrm{ab}$ & $86.7 \mathrm{a}$ & $100 \mathrm{a}$ & $93.3 \mathrm{ab}$ \\
\hline & Corvallis, OR & $68.3 \mathrm{a}$ & $64.5 \mathrm{ab}$ & $96.7 \mathrm{ab}$ & $86.7 \mathrm{a}$ & $93.3 \mathrm{ab}$ & $93.3 \mathrm{ab}$ \\
\hline \multirow[t]{3}{*}{ Liberty } & Geneva, NY & $74.1 \mathrm{a}$ & $55.5 \mathrm{abc}$ & $100 \mathrm{a}$ & $66.7 \mathrm{a}$ & $96.7 \mathrm{a}$ & $100 \mathrm{a}$ \\
\hline & Davis, CA & $70.2 \mathrm{a}$ & $61.5 \mathrm{abc}$ & $93.3 \mathrm{ab}$ & $73.3 \mathrm{a}$ & $100 \mathrm{a}$ & $96.7 \mathrm{ab}$ \\
\hline & Corvallis, OR & $93.8 \mathrm{a}$ & $96.2 \mathrm{a}$ & $93.3 \mathrm{ab}$ & $73.3 \mathrm{a}$ & $100 \mathrm{a}$ & $100 \mathrm{a}$ \\
\hline
\end{tabular}

${ }^{\mathrm{z}}$ Means in the same column followed by the same letter are not significantly different at $P=0.05$.

$\mathrm{LNV}=$ liquid nitrogen vapor.

cooling cabinet and were exposed to the same conditions. In 2007, twigs were harvested at the end of January, but in the two other years, the harvest occurred $\approx 16$ (2008) to 18 (2009) d earlier, but within each year, the harvest time was similar in all three locations (Table 2). The time from harvest to processing (i.e., the twig exposure to $-5{ }^{\circ} \mathrm{C}$ storage) varied between the years and was the shortest in 2007 ( 5 to 6 d) and the longest in 2009 (Table 2), but like with harvest time was similar within each year for Geneva and Corvallis (22d), yet shorter for Davis (14d).

A significant interaction $(P 0.05)$ between the year and cultivar for DB survival in LNV was observed; however, the interactions between location and cultivar and location and year were not significant (Table 10). In the control viabilities, there were significant interactions between the location and cultivar and location and year.

These data suggest that cryopreservation of the DB did not adversely affect the survival of the DB from the three sites and over the 3 years beyond what would be seen with desiccation and slow cooling (Tables 8 and 9). Based on the 3-year average, survival of buds from Geneva was significantly less than survival of buds from Corvallis but not significantly different from Davis (Tables 7 and 8).

All of the cultivars had good viability after cryopreservation. When comparing the mean viability for the three cultivars collectively over the 3-year period (2007 to 2009), only 'Braeburn' had significantly lower viability than 'Liberty'. No significant differences were observed between viabilities of 'Jonagold' and 'Liberty' or 'Braeburn' and 'Jonagold' in any of the 3 years of the study with the years analyzed individually or collectively. Differences in post-cryopreservation viabilities between cultivars or accessions are not unusual and indeed were expected. Although Towill et al. (2004) mentioned the effect of year and
Table 7. Mean post-cryopreservation viability (\%) of apple dormant buds for three locations during 2007 to 2009 that were cooled to $-30{ }^{\circ} \mathrm{C}$ or cooled to $-30{ }^{\circ} \mathrm{C}$ and stored in LNV, rehydrated, and grafted onto rootstocks.

\begin{tabular}{lll}
\hline Cultivar & $-30{ }^{\circ} \mathrm{C}$ & LNV \\
\hline Braeburn & $74.4 \mathrm{~b}^{\mathrm{z}}$ & $64.4 \mathrm{~b}$ \\
Jonagold & $80.6 \mathrm{ab}$ & $76.4 \mathrm{ab}$ \\
Liberty & $92.8 \mathrm{a}$ & $80.1 \mathrm{a}$ \\
\hline
\end{tabular}

${ }^{\mathrm{z}}$ Means in the same column followed by the same letter are not significantly different at $P=0.05$. $\mathrm{LNV}=$ liquid nitrogen vapor.

cultivar on apple cryosurvival, our study demonstrated no cryosurvival differences between Davis and Corvallis and Davis and Geneva for 2 of the 3 years of the study (Table 8).

The average post-cryopreservation DB viabilities between the sites when cultivars or years are taken collectively indicate only 2007 yielded a significant difference as perhaps the result of equipment malfunction as explained previously. If only 2008 and 2009 are analyzed, there is no significant difference in viabilities among the three sites. Surprisingly, despite a lack of significant differences, the post-cryopreservation viabilities were highest from Corvallis and lowest from Geneva. Although differences were not significant, it is interesting to ask whether an environmental attribute might account for the lower viability of cryopreserved DB from Geneva, which is clearly colder; hence, one would infer that these buds might be more cold-hardy. In contrast, it is clear that whatever the physiological attribute, be it cold-hardiness or degree of dormancy, DB from trees grown in either Corvallis or Davis attained this physiological requirement.

In a study on Haralson apple cold acclimation (Pyrus malus L.), short day and frost were suggested to regulate the acclimation process (Howell and Weiser, 1970). Sakai (1965) reported that cold-hardy woody plants 
Table 8. Mean post-cryopreservation viability (\%) of three cultivars of apple dormant buds harvested at three locations during 2007 to 2009 that were cooled to $-30{ }^{\circ} \mathrm{C}$ or cooled to $-30{ }^{\circ} \mathrm{C}$ and stored in LNV, rehydrated, and grafted onto rootstocks.

\begin{tabular}{|c|c|c|c|c|c|c|c|c|}
\hline \multirow[b]{2}{*}{ Location } & \multicolumn{2}{|c|}{2007} & \multicolumn{2}{|c|}{2008} & \multicolumn{2}{|c|}{2009} & \multicolumn{2}{|c|}{ Three-yr avg } \\
\hline & $-30^{\circ} \mathrm{C}$ & LNV & $-30^{\circ} \mathrm{C}$ & LNV & $-30{ }^{\circ} \mathrm{C}$ & LNV & $-30^{\circ} \mathrm{C}$ & LNV \\
\hline Geneva, NY & $50.1 \mathrm{a}^{\mathrm{z}}$ & $40.1 \mathrm{~b}$ & $84.4 \mathrm{a}$ & $71.1 \mathrm{a}$ & $79.7 \mathrm{a}$ & $78.9 \mathrm{a}$ & $71.4 \mathrm{~b}$ & $63.4 \mathrm{~b}$ \\
\hline Davis, CA & $54.4 \mathrm{a}$ & $54.5 \mathrm{ab}$ & $89.4 \mathrm{a}$ & $74.2 \mathrm{a}$ & $89.2 \mathrm{a}$ & $77.5 \mathrm{a}$ & $77.7 \mathrm{ab}$ & $68.7 \mathrm{ab}$ \\
\hline Corvallis, OR & $83.3 \mathrm{a}$ & $77.4 \mathrm{a}$ & $95.6 \mathrm{a}$ & $77.8 \mathrm{a}$ & $90.1 \mathrm{a}$ & $87.8 \mathrm{a}$ & $89.7 \mathrm{a}$ & $81.0 \mathrm{a}$ \\
\hline
\end{tabular}

${ }^{\mathrm{z}}$ Means in the same column followed by the same letter are not significantly different at $P=0.05$.

$\mathrm{LNV}=$ liquid nitrogen vapor.

Table 9. Mean post-cryopreservation viability (\%) of three cultivars of apple dormant buds harvested at New York, California, and Oregon that were cooled to $-30{ }^{\circ} \mathrm{C}$ or cooled to $-30{ }^{\circ} \mathrm{C}$ and stored in LNV, rehydrated, and grafted onto rootstocks.

\begin{tabular}{lll}
\hline $\mathrm{Yr}$ & $-30{ }^{\circ} \mathrm{C}$ & LNV \\
\hline 2007 & $63.7 \mathrm{~b}^{\mathrm{z}}$ & $58.4 \mathrm{~b}$ \\
2008 & $89.8 \mathrm{a}$ & $74.3 \mathrm{a}$ \\
2009 & $85.7 \mathrm{a}$ & $81.0 \mathrm{a}$ \\
\hline
\end{tabular}

${ }^{\mathrm{z}}$ Means in the same column followed by the same letter are not significantly different at $P=0.05$.

$\mathrm{LNV}=$ liquid nitrogen vapor.

tolerated liquid nitrogen exposure better than less cold-hardy. Tyler and Stushnoff (1988a, 1988b) observed higher dormant bud cryosurvival for apple cultivars derived at colder climate zones than cultivars developed at warmer geographical zones. In our study, the same cultivars were used from the three locations; hence, their geographic origin was not a factor. The same authors reported the effect of moisture content of twig sections before $\mathrm{LN}_{2}$ exposure on the dormant bud post-cryopreservation viability. In this study, moisture content was also not a variable because all material was desiccated to $25 \%$ to $30 \%$ MC before LNV exposure. Likewise, twig harvest time was shown as a factor influencing viability of cryopreserved dormant apple buds (Seufferheld et al., 1999; Tyler and Stushnoff, 1988a, 1988b); however, harvest time was not a variable in our study because twigs from the three locations were harvested at the same time within each year. In the previous studies with cold-tender apple buds, the highest survival after $-30{ }^{\circ} \mathrm{C}$ exposure was observed for buds harvested in November at Geneva, NY. In our study, the Geneva preharvest temperature was the lowest among the locations; therefore, the Geneva DBs were thought to be the best cold-acclimated. However, the Geneva DB cryosurvival was the lowest, although not significantly different from the cryosurvival of DB from Davis, CA, and DB from Davis were most likely less cold-acclimated based on temper- atures at this location. It can also be concluded that the Corvallis DB were likely less cold-acclimated than the Geneva DB, yet DB from Corvallis showed a significantly higher post-cryopreservation survival than the Geneva DB.

Stushnoff (1991) and Tyler et al. (1988) reported that the level and duration of prefreezing temperature before $\mathrm{LN}_{2}$ immersion influenced survival of apple DB. Stushnoff (1991) suggested that DB cryopreservability of temperate fruit crops was related to their desiccation tolerance and cold-hardiness. Furthermore, Forsline et al. (1998) reported that DB of cold-tender apple accessions showed a lower cryotolerance even at maximum coldhardiness than cold-hardy. All three cultivars used in our study are rated as intermediate in cold-hardiness and were exposed to different temperatures at the three locations before their harvest (Table 2). Hence, the purpose of the present study was not to test a difference between cultivars with different cold-hardiness ratings, but rather to test if the physical geographic location of the $\mathrm{DB}$, and by interference the preharvest temperature, compromised cryotolerance. The data show that for the three locations tested, the geographic location of the DB harvest did not adversely affect the DB cryopreservability.

Results from these previous studies (Stushnoff, 1991; Tyler and Stushnoff 1988a, 1988b; Tyler et al., 1988) were used in the development of the apple DB cryopreservation method (Forsline et al., 1998). This method has been used very successfully, yet the majority of the Malus cryopreservation research conducted at the NCGRP has used DB grown in Geneva, NY. With over 2400 Malus accessions from 48 species cryopreserved, and over 100 Malus accessions available for use today only because they were reintroduced to the field collection from cryopreserved material, DBs from this site are clearly physiologically suitable for cryopreservation. In the United States, the NPGS germplasm collections of temperate woody fruit and nut crops are predominately stored at three locations,

Table 10. Analysis of variance for interactions between cultivar, location, and year for postcryopreservation viability (\%) for three cultivars of apple dormant buds harvested at three locations during 2007 to 2009.

\begin{tabular}{|c|c|c|c|c|c|c|}
\hline$-30^{\circ} \mathrm{C}$ & Cultivar & Location & $\mathrm{Yr}$ & LNV & Cultivar & Location \\
\hline Cultivar & & & & Cultivar & & \\
\hline Location & $*$ & & & Location & NS & \\
\hline Year & NS & $*$ & & Year & $*$ & NS \\
\hline
\end{tabular}

* Significant at $P=0.05$.

LNV = liquid nitrogen vapor; NS = non-significant.
Geneva, NY, Davis, CA, and Corvallis, OR. Although the Geneva site is the highest in elevation (374 m versus $41 \mathrm{~m}$ and $75 \mathrm{~m}$, respectively; Table 1) and has the coldest minimum and average winter temperatures (November to January; Table 3), the Corvallis site is the most northern in latitude. The higher average and minimum winter temperatures at the Corvallis and Davis sites are likely the result of the lower elevation and proximity to the Pacific Ocean. Both sites are within 100 miles of the coast in agricultural valleys with milder winter conditions. In Geneva, snow cover is common for long periods during the winter, whereas at both Davis and Corvallis, winter snow cover is not common. Based on these data, it is clear that trees in Geneva, NY, are exposed to considerably longer and colder winter temperatures. Bud swelling and budbreak occur 3 to 4 weeks earlier in Davis and Corvallis than at the Geneva site.

Based on data from the three accessions of $M$. domestica, the growing locations of the apple DB source had little effect on their cryosurvival. These results lend a favorable prospect for cryopreservation of other dormant woody crops growing at clonal repositories through the United States and the perhaps other countries. For example, Lombardi et al. (in press) has also applied the Malus cryopreservation method successfully to DB of apples grown in the Veneto region of Italy. These data suggest that it is not the geographic location and associated environmental conditions that are limiting the application of the apple DB cryopreservation of the procedure to other crops grown in locations such as Davis, CA, and Corvallis, OR.

\section{Literature Cited}

Forsline, P.L., L.E. Towill, J.W. Waddell, C. Stushnoff, W.F. Lamboy, and J.R. McFerson. 1998. Recovery of cryopreserved dormant apple buds. J. Amer. Soc. Hort. Sci. 123: 365-370.

Hamilton, K.N., S.E. Ashmore, and H.W. Pritchard. 2009. Thermal analysis and cryopreservation of seeds of Australian wild Citrus species (Rutaceae): Citrus australasica, C. indora and C. garrawayi. Cryo Lett. 30:268-279.

Harvengt, L., A. Meier-Dinkel, E. Dumas, and E. Collin. 2004. Establishment of a cryopreserved gene bank of European elms. Can. J. For. Res. $34: 43-55$.

Howell, G.S. and C.J. Weiser. 1970. The environmental control of cold acclimation in apple. Plant Physiol. 45:390-394.

Kuoksa, T. and A. Hohtola. 1991. Freezepreservation of buds from Scots pine trees. Plant Cell Tissue Organ Cult. 27:89-93.

Lombardi, M., C. Benelli, A. DeCarlo, E.A. Ozudogru, A. Previati, and D. Ellis. Cryopreservation of ancient apple cultivars of Veneto: A comparison between PVS2 vitrification and dormant bud technique. Acta Hort. (in press).

Matsumoto, T., K. Mochida, H. Itamura, and A Sakai. 2001. Cryopreservation of persimmon (Diospyros kaki Thunb.) by vitrification of dormant shoot tips. Plant Cell Rep. 20:398-402.

Niino, T., K. Shirata, and S. Oka. 1995. Viability of mulberry winter buds cryopreserved for 5 years at $135^{\circ}$ C. J. Seric. Sci. Jpn. 64:370-374.

Nilsson, J.E. 2001. Seasonal changes in phenological traits and cold hardiness of $F_{1}$ populations 
from plus trees of Pinus sylvestris and Pinus contorta of various geographical origins. Scand. J. For. Res. 16:7-20.

Ryynänen, L. 1996. Survival and regeneration of dormant silver birch buds stored at super-low temperatures. Can. J. For. Res. 26:617-623.

Sakai, A. 1965. Survival of plant tissue at superlow temperatures. III. Relation between effective prefreezing temperatures and the degree of frost hardiness. Plant Physiol. 40:882887.

Sakai, A. and C.J. Weiser. 1973. Freezing resistance of trees in North America with reference to tree regions. Ecology 54:118-126.

Sakai, A. 1983. Comparative study on freezing resistance of conifers with special reference to cold adaptation and its evolutive aspects. Can. J. Bot. 61:2323-2332.

Seufferheld, M.J., C. Stushnoff, P.L. Forsline, and G.H.T. Gonzalez. 1999. Cryopreservation of cold-tender apple germplasm. J. Amer. Soc. Hort. Sci. 124:612-618.

Stushnoff, C. 1991. Cryopreservation of fruit crop genetic resources-Implications for maintenance and diversity during conservation. HortScience 26:518-522.
Suzuki, M., T. Niino, T. Akihama, and S. Oka. 1997. Shoot formation and plant regeneration of vegetative pear buds cryopreserved at 150 degrees C. J. Jpn. Soc. Hortic. Sci. 66:29-34.

Towill, L.E. and R. Bonnart. 2005. Cryopreservation of apple using non desiccated sections from winter-collected scions. Cryo Lett. 26:323-332.

Towill, L.E. and D.D. Ellis. 2008. Cryopreservation of dormant buds, p. 421-422. In: Reed, B. (ed.). Plant cryopreservation. A practical guide. Springer Science+Business, New York, NY.

Towill, L.E. and P.L. Forsline. 1999. Cryopreservation of sour cherry (Prunus cerasus L.) using a dormant vegetative bud method. Cryo Lett. 20:215-222.

Towill, L.E., P.L. Forsline, C. Walters, J.W Waddell, and J. Laufmann. 2004. Cryopreservation of Malus germplasm using a winter vegetative bud method: Results from 1915 accessions. Cryo Lett. 25:323-334.

Towill, L.E. and M. Widrlechner. 2004. Cryopreservation of Salix species using sections from winter vegetative scions. Cryo Lett. 25:71-80.

Tyler, N. and C. Stushnoff. 1988a. The effects of prefreezing and controlled dehydration on cryopreservation of dormant vegetative apple buds. Can. J. Plant Sci. 68:1163-1167.
Tyler, N. and C. Stushnoff. 1988b. Dehydration of dormant apple buds at different stages of cold acclimation to induce cryopreservability in different cultivars. Can. J. Plant Sci. 68:11691176.

Tyler, N., C. Stushnoff, and L.V. Gusta. 1988. Freezing of water in dormant vegetative apple buds in relation to cryopreservation. Plant Physiol. 87:201-205.

Volk, G.M., R. Bonnart, J. Waddell, and M.P. Widrlechner. 2009. Cryopreservation of dormant buds from diverse Fraxinus species. Cryo Lett. 30:262-267.

Volk, G.M., J. Waddell, R. Bonnart, L. Towill, D. Ellis, and J. Luffman. 2008. High viability of dormant Malus buds after 10 years of storage in liquid nitrogen vapor. Cryo Lett. 29:89-94

Zhen, Y. 2009. Natural variation in freezing tolerance in Arabidopsis thaliana. $\mathrm{PhD}$ dissertation, Division of Biology, Kansas State University, Manhattan, KS.

Zhen, Y. and M.C. Ungerer. 2008. Clinal variation in freezing tolerance among natural accessions of Arabidopsis thaliana. New Physiologist 177:419 427. 